\title{
On-farm evaluation of seed yield and oil quality of linseed (Linum usitatis- simum L.) in inland areas of Tuscany, Central Italy
}

\author{
Luciana G. Angelini, Silvia Tavarini, Daniele Antichi, Lara Foschi, Marco Mazzoncini \\ Department of Agriculture, Food and Environment, University of Pisa, Italy
}

\begin{abstract}
Traditional oilseed crops, such as linseed (Linum usitatissimum L.), may represent valuable alternative crops in cropping systems dominated by cereals, due to their adaptability to poor soils and to their high economic value related to the interesting quality of the oil, which is being increasingly appreciated by consumers and industry. The aim of this study was to test the adaptability of linseed to the inland marginal areas of Tuscany, and to explore the levels of crop yield and oil quality which can be achieved in hilly and lowland environments. For three years (2011-2014), experimental open fields (15 ha each) were established and monitored in six commercial farms located in the inland countryside of Pisa province, Tuscany, Central Italy. The effect of environment (hilly and plain areas) was assessed in terms of yield and yield components as well as oil content and composition. Interestingly, seed yield and biomass production were very stable over years in the two areas of cultivation, irrespectively of yearly differences in weather conditions. As expected, higher yields were obtained in plain than in hilly areas. Regarding oil composition, oil extracted from linseed grown in plain environments was richer in
\end{abstract}

Correspondence: Luciana G. Angelini, Department of Agriculture, Food and Environment, University of Pisa, via del Borghetto 80, 56124 Pisa, Italy.

Tel.: +39.050.2218901. E-mail: luciana.angelini@unipi.it

Key words: Crop production; marginal lands; oilseed crops; linseed.

Acknowledgements: the authors are grateful to Dr. Massimo Sbrana and to the staff of CiRAA Enrico Avanzi for their precious scientific and technical support.

Funding: this research was financially supported by the PSR 2007-2013 of Tuscany Region (Project IMES-SEMI-Mis.124 Sviluppo di prodotti e processi innovativi per la produzione di oli e panelli vegetali).

Conference presentation: SIA XLIV Congress, Bologna, 2015.

Received for publication: 16 December 2015.

Revision received: 18 April 2016.

Accepted for publication: 20 April 2016.

(C) Copyright L.G. Angelini et al., 2016

Licensee PAGEPress, Italy

Italian Journal of Agronomy 2016; 11:736

doi:10.4081/ija.2016.736

This article is distributed under the terms of the Creative Commons Attribution Noncommercial License (by-nc 4.0) which permits any noncommercial use, distribution, and reproduction in any medium, provided the original author(s) and source are credited. linolenic acid, while, oppositely, both oleic and linoleic acids were more abundant in oil from hilly areas. Definitively, our results demonstrated that linseed might be a valuable alternative to cereal crops for marginal lands of Tuscany and, more in general, of Central Italy.

\section{Introduction}

Marginal lands are defined as areas with little agricultural value, because of several environmental and socio-economic constraints, which negatively affect crop productivity and produce quality, leading to very low farmer income. For these reasons, these lands were progressively abandoned by inhabitants, moving to the urban areas looking for other opportunities. On the other hand, marginal lands can be very valuable from an environmental point of view, being part of partially naturalised ecosystems, hosting important specimens of plants and animals. Agriculture plays a crucial role in this context in terms of soil conservation, due to the maintenance of hydraulic infrastructures and the contrasting of soil erosion. In Central Italy, marginal lands are mainly located in inland countryside, characterised by hills and mountains, where agricultural production is mainly based on pastures for sheep, goats and cattle, or on winter cereals. Due to the clay texture of the soil and the low water intake, winter cereals (i.e., wheat, oats, barley, einkorn and emmer) are the dominating species, with very few alternatives for farmers, which are mostly grain or forage legumes, such as sulla (Hedisarum coronarium L.) and clovers. The recent trends of the market of cereal grain, characterised by low levels of the prices, caused many farmers abandoning crop production for economic reasons. Furthermore, the crop diversification measures included in the greening payment of the new European Common Agricultural Policy (EU CAP) 2014-2020 makes crucial for farmers to find new crops to include in crop rotations. Traditional oilseed crops like linseed (Linum usitatissimum L.) may represent a valuable alternative to grain cereals in cropping systems dominated by cereals, due to their adaptability to poor soils and to their high economic value related to the high quality of the oil, which is being increasingly appreciated by consumers and by the industry of food, cosmetics and ecomaterials (Zanetti et al., 2013). The oil of linseed, for instance, is well know to contain several polyunsaturated fatty acids, such as linoleic and linolenic acids (Alonso and Maroto, 2000), which are present in a very stable proportion (Andruszczak et al., 2015). Compared to other oilseed crops, it is the richest source of n$3 \alpha$-linolenic acid, which has a beneficial effect on the prevention of diseases of affluence (Oomah, 2001).

The aim of this study was to test the adaptability of linseed to the inland marginal areas of Tuscany and to explore the levels of crop yield and oil quality which can be achieved in hilly and lowland environments. 


\section{Materials and methods}

For three years (2011-2014), experimental open fields (1-5 ha each) were established and monitored in 6 commercial farms located in the inland countryside of Pisa province, Tuscany, Central Italy. Three of the six farms were located in hilly areas (Santa Luce, $43^{\circ} 28^{\prime} 0^{\prime \prime} \mathrm{N}$, $10^{\circ} 34^{\prime} 0^{\prime \prime} \mathrm{E}, 200 \mathrm{~m}$ a.s.l.), whilst the remaining three in plain areas (Cascina, $43^{\circ} 40^{\prime} 48^{\prime \prime} \mathrm{N}, 10^{\circ} 30^{\prime} 1$ 'E, $8 \mathrm{~m}$ a.s.l.), but all mainly produced winter cereals according to the integrated pest management (IPM) standards. Farm acreage ranged from 10 to 200 ha. Soil types were quite homogeneous in the two groups of farms, with clay-loam soils

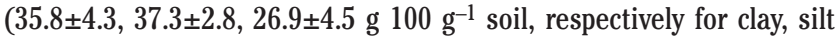
and sand), with poor soil organic matter $\left(1.29 \pm 0.42 \mathrm{mg} \mathrm{g}^{-1}\right.$ soil $)$, total nitrogen $\left(1.11 \pm 0.07 \mathrm{mg} \mathrm{g}^{-1}\right.$ soil) and available phosphorus $(3.22 \pm 0.72$ $\mathrm{mg} \mathrm{P}_{2} \mathrm{O}_{5} \mathrm{~g}^{-1}$ soil) content in hilly areas, and loam soils $(20.1 \pm 7.1$, $42.4 \pm 2.7,37.5 \pm 6.7 \mathrm{~g} 100 \mathrm{~g} \mathrm{~g}^{-1}$ soil, respectively for clay, silt and sand) more rich in total nitrogen $\left(1.31 \pm 0.21 \mathrm{mg} \mathrm{g}^{-1}\right.$ soil), organic matter $\left(1.82 \pm 0.46 \mathrm{mg} \mathrm{g}^{-1}\right.$ soil) and available phosphorus $\left(6.27 \pm 2.41 \mathrm{mg} \mathrm{P}_{2} \mathrm{O}_{5}\right.$ $\mathrm{g}^{-1}$ soil) in plain areas. Total annual rainfall were 382,948 and 1188 $\mathrm{mm}$, respectively, for 2011/12, 2012/13 and 2013/14, and were more abundant from October to April. Mean temperatures ranged from $4^{\circ} \mathrm{C}$ (February) to $25^{\circ} \mathrm{C}$ (August), from $6^{\circ} \mathrm{C}$ (February) to $25^{\circ} \mathrm{C}$ (July) and from $8^{\circ} \mathrm{C}$ (December) to $22^{\circ} \mathrm{C}$ (July), respectively for first, second and third year.

Crop technique was implemented differently in the two areas according to standard practices applied by local farmers. In the hilly areas, the soil was ploughed down to $35 \mathrm{~cm}$ depth in September, whilst in plain areas chiselling $35 \mathrm{~cm}$ depth was the main tillage. The seedbed was prepared in both environments with two passes of disk harrow in October. Brown-seeded linseed (cv. Sideral) was sown in all the farms on around November 15 2011, October 182012 and October 302013 at a constant seeding rate of $40 \mathrm{~kg} \mathrm{ha}^{-1}$, with an inter-row distance of 13 $\mathrm{cm}$. According to farmers' standard practices, phosporus (P) fertiliser was applied before main tillage as superphosphate (at a rate corresponding to 44 and $57 \mathrm{~kg} \mathrm{P}_{2} \mathrm{O}_{5}$ ha $^{-1}$, respectively for plain and hilly areas), whilst nitrogen (N) was top dress applied as urea in hilly areas (at 100 $\mathrm{kg} \mathrm{N} \mathrm{ha}^{-1}$ ), as ammonium nitrate in plain areas (at $80 \mathrm{~kg} \mathrm{~N} \mathrm{ha}^{-1}$ ). Postemergence herbicides were applied differently in the two areas $(330 \mathrm{~g}$ $\mathrm{ha}^{-1}$ bromoxynil octanoate $+4 \mathrm{~g} \mathrm{ha}^{-1}$ metsulfuron methyl in plain areas, $50 \mathrm{~g} \mathrm{ha}^{-1}$ quizalofop-p-ethyl $+4 \mathrm{~g} \mathrm{ha}^{-1}$ metsulfuron methyl in hilly areas). Harvest occurred at seed maturity (seed moisture lower than 9\%) in early August in the last two years, whilst in the first one it was performed earlier (on July 7) due to the drier conditions.

Linseed density (no. of plants $\mathrm{m}^{-2}$ ), seed dry yield $\left(\mathrm{Mg} \mathrm{ha}^{-1}\right)$, residues dry biomass $\left(\mathrm{Mg} \mathrm{ha}^{-1}\right)$ and harvest index (\%) were assessed by collecting plants on 4 sampling areas $10 \mathrm{~m}^{2}$ each per plot at harvest time. Also the actual seed yield of the entire fields was assessed by collecting all the seeds harvested by the combine machine. Dry matter of seeds and residues were measured after oven-drying fresh materials at $60^{\circ} \mathrm{C}$ until constant weight. Seed protein content was measured according to the Kjeldahl method (Bremner and Mulvaney, 1982) (Kjeldahl N $\times$ 6.25). Samples were analysed for oil content according to the Association of Official Analytical Chemists (AOAC) methods (AOAC, 2000). Ether extract system was used for oil extraction from powdered samples, by an ANKOM model XT10 extractor (ANKOM Technology, Macedon, NY, USA). In a typical extraction process, $1 \mathrm{~g}$ powdered samples were immersed in boiling petroleum ether for $60 \mathrm{~min}$ to dissolve most of the soluble material. Total lipids were extracted by means of a chloroform/methanol solution $(2: 1, \mathrm{v} / \mathrm{v})$, according to RodriguezEstrada et al. (1997). An acid transmethylation was used to prepare fatty acids (FA) for the analysis of oil composition. For the analysis was used a GC2010 Shimadzu gas chromatograph (Shimadzu Scientific Instrument, Columbia, MD, USA) equipped with a flame-ionisation detector and a high polar fused-silica capillary column (Chrompack CPSil88; Varian Chrompack, Middelburg, the Netherlands; $100 \mathrm{~m}, 0.25 \mathrm{~mm}$ i.d.; film thickness $0.20 \mu \mathrm{m})$. Individual FA methyl esters were identified by comparison with a standard mixture of 52 Component FAME Mix (Nu-Chek Prep Inc., Elysian, MN, USA).

The effect of environment (hilly and lowland areas) and of cultivation year was assessed by linear mixed-model with lme4 package (Bates et al., 2014) of R statistical software (R Core Team, 2015). For crop biomass parameters (Table 1) the effect of the two factors was significant, therefore the data were analysed separately for each year with a t-test with three replications (Gomez and Gomez, 1984). As the effect of cultivation year was not significant for oil composition, for this parameter the effect of the two areas was tested on the means averaged over the three years.

\section{Results and discussion}

Crop production parameters at harvest time are reported in Table 1. Overall, crop yield levels in both environments were in line with previous results obtained with different varieties in Central Italy (D’Antuono and Rossini, 2006) and other countries (Lafond et al., 2008; Bilalis et al., 2010; May et al., 2010; Pageau and Lajeunesse, 2011; Dordas, 2012; Filipovic et al., 2014; Xie et al., 2014; Andruszczak et al., 2015). Interestingly, seed yield, oil yield and biomass production of linseed were very stable over years in the two areas of cultivation, irrespectively of yearly differences in weather conditions. As expected, linseed yielded significantly higher in lowland than in hilly areas. Nevertheless, in hilly farms seed yields in sampling areas, were accept-

Table 1. Plant number, seed yield, dry biomass of aboveground crop residues (stems+leaves+capsules), harvest index, oil yield and seed yield of entire fields of linseed in the two areas and in the three years (mean \pm standard deviation).

\begin{tabular}{|c|c|c|c|c|c|c|}
\hline & \multicolumn{2}{|c|}{2012} & \multicolumn{2}{|c|}{2013} & \multicolumn{2}{|c|}{2014} \\
\hline & Lowland area & Hilly area & Lowland area & Hilly area & Lowland area & Hilly area \\
\hline Plant density $\left(\mathrm{m}^{-2}\right)$ & $454.4 \pm 35.6^{\mathrm{a}}$ & $336.1 \pm 16.1^{\mathrm{b}}$ & $394.6 \pm 45.2^{\mathrm{a}}$ & $205.5 \pm 21.5^{\mathrm{b}}$ & $213.1 \pm 25.5^{b}$ & $525.1 \pm 19.6^{\mathrm{a}}$ \\
\hline Seed yield $\left(\mathrm{Mg} \mathrm{ha}^{-1}\right)$ & $3.04 \pm 0.08^{\mathrm{a}}$ & $1.43 \pm 0.11^{\mathrm{b}}$ & $3.06 \pm 0.26^{\mathrm{a}}$ & $1.62 \pm 0.54^{b}$ & $2.94 \pm 0.80^{\mathrm{a}}$ & $1.39 \pm 0.16^{b}$ \\
\hline Residues dry biomass $\left(\mathrm{Mg} \mathrm{ha}^{-1}\right)$ & $7.28 \pm 0.90^{\mathrm{a}}$ & $3.24 \pm 0.35^{b}$ & $7.69 \pm 0.13^{\mathrm{a}}$ & $4.57 \pm 0.52^{b}$ & $7.20 \pm 0.87^{\mathrm{a}}$ & $3.07 \pm 0.49^{b}$ \\
\hline Harvest index & $0.29 \pm 0.09^{\mathrm{a}}$ & $0.31 \pm 0.09^{a}$ & $0.28 \pm 0.02^{\mathrm{a}}$ & $0.26 \pm 0.07^{a}$ & $0.29 \pm 0.04^{\mathrm{a}}$ & $0.31 \pm 0.02^{\mathrm{a}}$ \\
\hline Actual seed yield $\left(\mathrm{Mg} \mathrm{ha}^{-1}\right)$ & $2.16 \pm 0.20^{\mathrm{a}}$ & $0.77 \pm 0.09^{b}$ & $1.40 \pm 0.14^{\mathrm{a}}$ & $0.40 \pm 0.06^{\mathrm{b}}$ & $1.67 \pm 0.05^{\mathrm{a}}$ & $0.50 \pm 0.04^{b}$ \\
\hline Oil yield $\left(\mathrm{Mg} \mathrm{ha}^{-1}\right)$ & $0.95 \pm 0.03^{\mathrm{a}}$ & $0.52 \pm 0.04^{b}$ & $0.96 \pm 0.06^{\mathrm{a}}$ & $0.54 \pm 0.02^{b}$ & $0.92 \pm 0.03^{\mathrm{a}}$ & $0.50 \pm 0.04^{b}$ \\
\hline
\end{tabular}

$\mathrm{a}, \mathrm{b}$ For each year, values in each row followed by the same letter are not significantly different at the 0.05 probability level. 
able for local standards. Crop establishment was constantly poorer in hilly areas, due to worse soil conditions and lower temperatures around sowing date. Only in the last year a higher plant density was observed in hilly than in lowland areas, without any yield increase still. Early sowing (i.e., in fall-winter) is thus not recommended for cooler climate conditions as in hilly areas, as demonstrated also in many studies carried out in Canada for spring sown varieties (Gusta et al., 1997; Hocking et al., 1997; Lafond et al., 2008).

Averaged over three years, crude protein seed content was signifi-

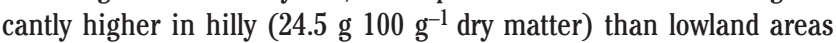

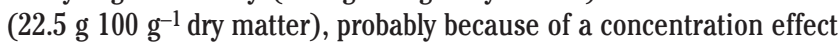
due to the lower yields. The same trend was observed also for oil seed

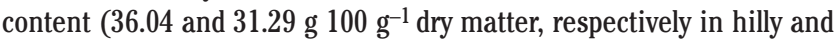
lowland areas).

Compared to that from hilly areas, oil extracted from linseed grown in lowland areas was richer in linolenic acid (Table 2). Oppositely, both oleic (monounsaturated) and linoleic (polyunsaturated) acids were more abundant in oil from hilly areas. Overall, the ratio between unsaturated and saturated fatty acids was higher in oil from lowland than hilly areas. Anyway, oil composition in both environments was similar to that of commercial linseed oil, as reported by Nykter et al. (2006) and was in line with other studies (Lafond et al., 2008; Singh et al., 2011; Angelini et al., 2015).

\section{Conclusions}

Our results demonstrated that linseed might be a valuable alternative to cereal crops for marginal lands of Tuscany and, more in general, of Central Italy. Besides an acceptable level of seed yields, also the quantity and quality of oil extracted from seeds was really good if com-

Table 2. Fatty acid composition of linseed oil (\%, mean \pm standard deviation; values are means over the three years).

\begin{tabular}{lcc}
\hline Fatty acids $(\%)$ & Lowland area & Hilly area \\
Myristic $\left(\mathrm{C}_{14: 0}\right)$ & $0.04 \pm 0.00^{\mathrm{b}}$ & $0.06 \pm 0.00^{\mathrm{a}}$ \\
Palmitic $\left(\mathrm{C}_{16: 0}\right)$ & $5.50 \pm 0.16^{\mathrm{b}}$ & $6.48 \pm 0.07^{\mathrm{a}}$ \\
\hline Palmitoleic $\left(\mathrm{C}_{16: 1 \mathrm{n}-\mathrm{-}}\right)$ & $0.06 \pm 0.00^{\mathrm{b}}$ & $0.12 \pm 0.00^{\mathrm{a}}$ \\
Stearic $\left(\mathrm{C}_{18: 0}\right)$ & $3.39 \pm 0.04^{\mathrm{b}}$ & $5.43 \pm 0.18^{\mathrm{a}}$ \\
\hline Oleic $\left(\mathrm{C}_{18: 1 \mathrm{n}-9}\right)$ & $18.77 \pm 0.67^{\mathrm{b}}$ & $22.91 \pm 0.97^{\mathrm{a}}$ \\
Vaccenic $\left(\mathrm{C}_{18: 1 \mathrm{n}-11}\right)$ & $0.76 \pm 0.10^{\mathrm{b}}$ & $0.97 \pm 0.01^{\mathrm{a}}$ \\
\hline Linoleic $\left(\mathrm{C}_{18: 2 \mathrm{n}-\mathrm{b}}\right)$ & $13.69 \pm 1.17^{\mathrm{b}}$ & $15.65 \pm 0.43^{\mathrm{a}}$ \\
Linolenic $\left(\mathrm{C}_{18: 3 \mathrm{n}-3}\right)$ & $56.47 \pm 0.21^{\mathrm{a}}$ & $46.94 \pm 0.67^{\mathrm{b}}$ \\
\hline Arachidic $\left(\mathrm{C}_{20: 0}\right)$ & $0.13 \pm 0.01^{\mathrm{b}}$ & $0.18 \pm 0.01^{\mathrm{a}}$ \\
Behenic $\left(\mathrm{C}_{22: 0}\right)$ & $0.13 \pm 0.02^{\mathrm{b}}$ & $0.18 \pm 0.01^{\mathrm{a}}$ \\
\hline Lignoceric $\left(\mathrm{C}_{24: 0}\right)$ & $0.10 \pm 0.01^{\mathrm{a}}$ & $0.12 \pm 0.01^{\mathrm{a}}$ \\
Others & $0.95 \pm 0.02^{\mathrm{a}}$ & $0.95 \pm 0.00^{\mathrm{a}}$ \\
\hline Total SFA & 9.29 & 12.45 \\
Total MUFA & 19.59 & 24.00 \\
\hline Total PUFA & 70.16 & 62.59 \\
PUFA/SFA ratio & 7.55 & 5.03 \\
\hline PUFA+MUFA/SFA ratio & 9.66 & 6.96 \\
\hline
\end{tabular}

SFA, saturated fatty acids; MUFA, monounsaturated fatty acids; PUFA, polyunsaturated fatty acids. $\mathrm{a}, \mathrm{b} V a$ lues in each row followed by the same letter are not significantly different at the 0.05 probability level. pared to market standards. Furthermore, the high amount of crop residues that can be returned to the soil after crop harvest can contribute to the sustainability of cropping systems in terms of conservation of soil organic matter. In our study, the lower productivity of the crop in hilly areas was likely due to the effect of environmental conditions (i.e., soil and climate), but also to the crop management, which was not fine-tuned specifically for the environment. In this sense, further research efforts are needed in optimisation of crop technique (e.g., optimal seeding date and rate, fertilisation, tillage) for such environmentally constrained areas.

\section{References}

Alonso FG, Maroto FG, 2000. Plants as 'chemical factories' for the production of polyunsaturated fatty acids. Biotech. Adv. 18:481-97.

Andruszczak S, Gawlik-Dziki U, Kraska P, Kwiecinska-Poppe E, Rozylo K, Palys E, 2015. Yield and quality traits of two linseed (Linum usitatissimum L.) cultivars as affected by some agronomic factors. Plant Soil Environ. 61:247-52.

Angelini LG, Tavarini S, Mazzoncini M, Tuberoso CIG, 2015. Virgin oil production from novel and traditional oilseed crops grown in Central Italy: natural constituents and antioxidant activity. Agrochimica 59:155-72.

AOAC, 2000. Official methods of analysis (17 th Ed.). Association of Official Analytical Chemists, Washington, DC.

Bates D, Maechler M., Bolker B, Walker S, 2014. Ime4: Linear mixedeffects models using Eigen and S4. R package version 1.1-7. Available from: http://CRAN.R-project.org/package=lme4.

Bilalis DJ, Karkanis A, Papastylianou P, Patsiali S, Athanasopoulou M, Barla G, Kakabouki I, 2010. Response of organic linseed (Linum usitatissimum L.) to the combination of tillage systems, (minimum, conventional and no-tillage) and fertilization practices: Seed and oil yield production. Aust. J. Crop Sci. 4:700-5.

Bremner JM, Mulvaney CS, 1982. Nitrogen total. In: AL Page, RH Miller, DR Keeney (Eds.), Methods of Soil Analysis, Part 2: Chemical and Microbiological Properties. American Society of Agronomy, Inc., Madison, WI. pp 595-624.

D'Antuono LF, Rossini F, 2006. Yield potential and ecophysiological traits of the Altamurano linseed (Linum usitatissimum L.), a landrace of southern Italy. Genet. Resour. Crop Ev. 53:65-75.

Dordas CA, 2012. Nitrogen and dry matter dynamics in linseed as affected by the nitrogen level and genotype in a Mediterranean environment. Biomass Bioenerg. 43:1-11.

Filipovic V, Popovic V, Glamoclija D, Jaramaz M, Jaramaz D, Andelovic S, Tabakovic M, 2014. Genotype and soil type influence on morphological characteristics, yield and oil content of oil-flax. Bulg. J. Agric. Sci. 20:79-86.

Gomez KA, Gomez AA, 1984. Statistical Procedures for Agricultural Research. John Wiley \& Sons, Hoboken, New Jersey, USA.

Gusta LV, Oconnor BJ, Bhatty RS, 1997. Flax (Linum usitatissimum L) responses to chilling and heat stress on flowering and seed yield. Can. J. Plant Sci. 77:97-9.

Hocking PJ, Kirkegaard JA, Angus JF, Gibson AH, Koetz EA, 1997. Comparison of canola, Indian mustard and Linola in two contrasting environments. 1.Effects of nitrogen fertilizer on dry-matter production, seed yield and seed quality. Field Crop Res. 49:107-25.

Lafond GP, Irvine B, Johnston AM, May WE, McAndrew DW, Shirtliffe SJ, Stevenson FC, 2008. Impact of agronomic factors on seed yield formation and quality in flax. Can. J. Plant Sci. 88:485-500.

May WE, Brandt SA, Gan Y, Kutcher HR, Holzapfel CB, Lafond GP, 2010. Adaptation of oilseed crops across Saskatchewan. Can. J. Plant Sci. 
90:667-77.

Nykter M, Kymalainen HR, Gates F, Sjoberg AM, 2006. Quality characteristics of edible linseed oil. Agr. Food Sci. 15:402-13.

Oomah BD, 2001. Flaxseed as a functional food source. J. Sci. Food Agr. 81:889-94.

Pageau D, Lajeunesse J, 2011. Effect of seeding date on oilseed flax grown in a cool climate. Can. J. Plant Sci. 91:29-35.

Rodriguez-Estrada MT, Penazzi G, Caboni MF, Bertacco G, Lercker G, 1997. Effect of different cooking methods on some lipid and protein components of hamburgers. Meat Sci. 45:365-75.

Singh KK, Mridula D, Rehal J, Barnwal P, 2011. Flaxseed: a potential source of food, feed and fibre. Crit. Rev. Food Sci. 51:210-22.

Xie Y, Niu J, Gan Y, Gao Y, Li A, 2014. Optimizing phosphorus fertilization promotes dry matter accumulation and $\mathrm{P}$ remobilization in oilseed flax. Crop Sci. 54:1729-36.

Zanetti F, Monti A, Berti MT, 2013. Challenges and opportunities for new industrial oilseed crops in EU-27: a review. Ind. Crop Prod. 50:580-95. 